\title{
KOMPETENSI MANAJERIAL KEPALA SEKOLAH MENENGAH KEJURUAN DALAM PENINGKATAN MUTU SEKOLAH DI SMK NEGERI SE-KOTA TANGERANG SELATAN
}

\author{
Dayat Hidayat $^{*}$, Subarto ${ }^{\star *}$, Wahyu Noviarti $\left.{ }^{\star \star *}\right)$ \\ wahyunovia27@gmail.com
}

\begin{abstract}
ABSTRAK
Kompetensi Manajerial Kepala Sekolah Menengah Kejuruan Dalam Peningkatan Mutu Sekolah Di SMK Negeri Se-Kota Tangerang Selatan. Penelitian ini membahas tentang kompetensi manajerial kepala sekolah untuk meningkatkan mutu sekolah, dan strategi peningkatan kompetensi manajerial kepala sekolah pada sekolah menengah kejuruan negeri di wilayah Kota Tangerang Selatan dalam peningkatan mutu sekolah. Penelitian ini merupakan penelitian kualitatif dengan jenis penelitian studi kasus. Subjek penelitian pada kali ini adalah kepala sekolah, guru dan siswa. Langkah yang diambil dalam tahap awal penelitian adalah melakukan observasi lapangan dan wawancara untuk mendapatkan data tersebut, serta data dianalaisa secara kualitatif menggunakan teknik SWOT (Strenght, Weekness, Opportunities, Threats). Hasil penelitian ini terkait dengan kompetensi manajerial kepala sekolah dalam perencanaan, pengorganisasian, pengarahan dan pengawasan, serta strategi menjalin kerjasama dengan lembaga pengembangan pendidikan dan manajerial sehingga dapat meningkatkan mutu sekolah menengah kejuruan negeri di wilayah Kota Tangerang Selatan.
\end{abstract}

Kata Kunci: Kompetensi, Manajerial, Mutu, Strenght, Weekness, Opportunities, Threats

\begin{abstract}
Managerial Competency Principal of Vocational High School in Improving School Quality in State Vocational High Schools in South Tangerang City. This study discusses the managerial competence of the headmaster to improve the quality of the school, and a strategy to increase the managerial competence of the school principal at a state vocational high school in the South Tangerang city region in increasing Quality of the school. This research is a qualitative study with the type of case study research. The subject of the study at this time was the principal, teacher and student. Steps taken in the early stages of research are doing field observations and interviews to get the data, as well as qualitative data analysed using SWOT techniques (Strenght, Weekness, Opportunities, Threats).The results of this research are related to the managerial competence of the principal in planning, organizing, directing and supervising, as well as strategies to establish cooperation with educational and managerial development agencies so as to improve Quality of state vocational high school in South Tangerang city.
\end{abstract}

Keywords: Competence, Managerial, Quality, Strength, weakness, Opportunities, Threats

\section{PENDAHULUAN}

\section{A. Latar Belakang}

Berbagai upaya telah dilakukan oleh pemerintah dalam rangka membenahi sistem manajemen pendidikan. Satu model pembenahan yang dilakukan pemerintah melalui kementerian pendidikan nasional (2013) adalah menerapkan4 (empat) level paradigma baru program pendidikan sekolah, yaitu (1) program pendidikan yang 
berorientasi broad-based education atau community based education, (2) pengembangan substansi materi yang berbasis kecakapan hidup (life skill), (3) pengelolaan proses belajar-mengajar yang berorientasi pada peningkatan mutu berbasis sekolah (school based quality improvement), dan (4) pelaksanaan manajemen yang sumber dayanya berorientasi pada manajemen berbasis sekolah (school based manajemen). Dari keempat model, pelaksanaan yang dilakukan di sekolah adalah model manajemen berbasis sekolah. Agar mampu menjadi kepala sekolah yang efektif dan efisien, Kepala sekolah harus memiliki sejumlah kompetensi. Kompetensi tersebut adalah kompetensi kepribadian, manajerial, sosial, supervisi, dan kewirausahaan seperti dalam Permendiknas No 13 tahun 2007. Kompetensi-kompetensi tersebut sudah sangat dimaklumi oleh siapa saja yang berkecimpung di dunia pendidikan, terutama mereka yang memiliki minat menjadi kepala sekolah dalam rangka melakukan pengabdian kepada bangsa secara lebih luas.

Kompetensi kepala sekolah yang sangat teknikal adalah kompetensi manajerial. Dengan demikian, apabila seseorang sudah menjadi kepala sekolah, khalayak memandang bahwa orang tersebut memiliki kompetensi manajerial secara baik. Menurut George R. Terry, 1958, Principles of Management (Sukarna, 2011: 10) terdapat empat fungsi dasar manajemen, yaitu Planning (Perencanaan), Organizing (Pengorganisasian), Actuating (Pelaksanaan), dan Controlling (Pengawasan).

Sejalan dengan hal tersebut, Sekolah Menengah Kejuruan (SMK) Negeri di wilayah Tangerang Selatan dalam menjalankan perannya turut serta dalam penyiapan sumber daya manusia yang memiliki daya saing harus mengacu kepada peraturan dan perundang-undangan yang berlaku di wilayah Negara Kesatuan Republik Indonesia. Bahkan, SMK Negeri di wilayah Tangerang Selatan adalah sekolah yang harus memiliki tata kelola dan manajerial sumber daya. Apabila pola perencanaan, pengadaan, pengorganisasian, pengerahan, pengendalian, dan pengawasan tidak dimiliki, maka SMK Negeri tidak memiliki daya saing dan kompetensi yang tepat. Ciri SMK Negeri di wilayah Tangerang Selatan merupakan sekolah yang didirikan oleh dinas pendidikan dan kebudayaan provinsi banten, memilki tenaga pendidik dan kependidikan yang memadai, jumlah ruang kelas yang cukup secara rasio, dan memiliki unit usaha sebagai laboratorium praktik usaha ekonomisiswa.

Bertambahnya jumlah siswa menunjukkan tanda semakin bermutunya layanan pendidikan yang diselenggarakan. Hal ini dapat dilihat pada tabel berikut:

Tabel 1.1 : Sebaran Jumlah Peserta Didik Tiga Tahun di Tangerang Selatan

\begin{tabular}{|c|c|c|c|c|}
\hline \multirow{2}{*}{ No. Nama Sekolah } & \multicolumn{3}{|c|}{ Jumlah Peserta Didik } \\
\cline { 3 - 5 } & $\mathbf{2 0 1 6 / 2 0 1 7}$ & $\mathbf{2 0 1 7 / 1 0 2 8}$ & $\mathbf{2 0 1 8 / 2 0 1 9}$ \\
\hline 1 & SMK Negeri 1 Kota Tangerang Selatan & 1207 & 1341 & 1360 \\
\hline 2 & SMK Negeri 2 Kota Tangerang Selatan & 1212 & 1244 & 1296 \\
\hline 3 & SMK Negeri 3 Kota Tangerang Selatan & 807 & 807 & 792 \\
\hline 4 & SMK Negeri 4 Kota Tangerang Selatan & 567 & 649 & 726 \\
\hline 5 & SMK Negeri 5 Kota Tangerang Selatan & 608 & 738 & 842 \\
\hline 6 & SMK Negeri 6 Kota Tangerang Selatan & 248 & 477 & 684 \\
\hline 7 & SMK Negeri 7 Kota Tangerang Selatan & 178 & 357 & 501 \\
\hline \multicolumn{2}{|c|}{ Jumlah } & $\mathbf{4 8 2 7}$ & $\mathbf{5 6 1 3}$ & $\mathbf{6 2 0 1}$ \\
\hline
\end{tabular}

Sumber : Data Pokok Pendidikan 2019 
Sedangkan sebaran jumlah pendidik dan tenaga kependidikan pada SMK Negeri di wilayah Tangerang Selatan yang terdaftar pada data pokok pendidikan kementerian pendidikan dan kebudayaan dapat kita lihat pada Tabel 1.2.

Tabel 1.2 : Sebaran Pendidik dan Tenaga Kependidikan di Tangerang Selatan

\begin{tabular}{|c|c|c|c|}
\hline No. & Nama Sekolah & Pendidik & Tenaga Kependidikan \\
\hline 1 & SMK Negeri 1 Kota Tangerang Selatan & 66 & 18 \\
\hline 2 & SMK Negeri 2 Kota Tangerang Selatan & 56 & 15 \\
\hline 3 & SMK Negeri 3 Kota Tangerang Selatan & 44 & 9 \\
\hline 4 & SMK Negeri 4 Kota Tangerang Selatan & 37 & 11 \\
\hline 5 & SMK Negeri 5 Kota Tangerang Selatan & 44 & 71 \\
\hline 6 & SMK Negeri 6 Kota Tangerang Selatan & 37 & 11 \\
\hline 7 & SMK Negeri 7 Kota Tangerang Selatan & 30 & 82 \\
\hline \multicolumn{2}{|c|}{ Jumlah } & 314 & \\
\hline
\end{tabular}

Sumber : Data Pokok Pendidikan 2019

Peraturan Pendidikan Nasional RI Nomor 13 Tahun 2007 tentang Standar Kepala Sekolah/Madrasah dipersyaratkan harus memiliki kompetensi sebagai berikut : (1) Kompetensi kepribadian, (2) Kompetensi manajerial, (3) Kompetensi kewirausahaan, (4) Kompetensi Supervisi, (5) Kompetensi sosial. Oleh karena itu kemampuan manajerial kepala sekolah sangat menarik untuk diteliti lebih mendalam, karena tidak semua kepala sekolah mampu melaksanakan tugas manajerial tersebut dengan baik, maka penulis sangat tertarik untuk meneliti lebih mendalam tentang kemampuan manajerial kepala sekolah dalam mengelola Sekolah Menengah Kejuruan Negeri di wilayah Tangerang Selatan sehingga menjadi sekolah yang efektif dan bermutu..

\section{B. Rumusan Masalah}

1. Bagaimana kompetensi manajerial kepala sekolah menengah kejuruan negeri di Kota Tangerang Selatan untuk meningkatkan mutu sekolah saat ini?

2. Bagaimana kompetensi manajerial kepala sekolah menengah kejuruan negeri di Kota Tangerang Selatan untuk meningkatkan mutu sekolah yang akan datang?

\section{KAJIAN TEORITIK}

\section{A. Manajerial}

Menurut Henry Fayol (1949) Manajerial terdiri dari 5 kriteria manajemen, yaitu :

1. Perencanaan (planning)

Suatu usaha atau upaya untuk merencanakan kegiatan yang akan dilaksanakan guna mencapai tujuan yang telah ditetapkan. Perencanaan ini biasanya dituangkan dalam bentuk konsep atau suatu program kerja sehingga organisasi denganberupa penentuan langkah-langkah yang memungkinkan organisasi mencapai tujuantujuannya.

2. Pengorganisasian (organizing)

Kegiatan yang meliputi penetapan struktur, tugas dan kewajiban, fungsi pekerjaan dan hubungan antar fungsi. Penetapan struktur organisasi beserta bagian-bagian dan tugas serta wewenang akan membantu pihak top manajemen untuk memantau setiap bagian dalam organisasi dan dapat dengan cepat 
mengkoordinir karyawan untuk menyelesaikan tugas dan kewajibannya. Dalam arti mobilisasi bahan materil dan sumber daya manusia guna melaksanakan rencana.

3. Memerintah (commanding)

Memerintah merupakan fungsi memberikan perintah atau arahan. Selain itu juga termasuk kegiatan kepemimpinan, bimbingan, motivasi pengarahan agar karyawan dapat bekerja dengan lebih efektif. Fungsi pengarahan lebih menjurus kepada fungsi kepemimpinan sebuah organisasi dimana seorang pimpinan dituntut mampu menggerakkan, mempengaruhi, memotivasi, mengajak, mengarahkan, membimbing, menasehati, menyuruh, memerintah, melarang dan bahkan menghukum serta membina dengan maksud agar manusia sebagai media menajemen mau bekerja dalam rangka mencapai tujuan administrasi secara efektif dan efisien.

4. Pengkoordinasian (coordinating)

Pengkoordinasian merupakan fungsi mengkoordinir seluruh pekerjaan dalam satu totalitas organisasi pekerjaan yang mengandung hal-hal sebagai berikut :
a. Sinkronisasi kegiatan
d. meruntutkan kegiatan
b. keterpaduan kegiatan
e. Mencegah overlaping dan kekosongan kegiatan
c. menyelaraskan kegiatan

5. Pengendalian (controlling)

Pengendalian merupakan fungsi yang memberikan penilaian, koreksi dan evaluasi atas semua kegiatan. Secara terus-menerus melakukan monitoring atas pekerjaan yang sedang dilakukan. Fungsi ini bertujuan untuk menyesuaikan rencana yang telah dicapai dengan pelaksanaan kegiatan. Hasil dari evaluasi pengawasan ini dijadikan sebagai bahan rekomendasi untuk kegiatan berikutnya. Dengan memantau rencana untuk membuktikan apakah rencana itu sudah dilaskanakan sebagaimana mestinya.

Dari definisi di atas dapat disimpulkan bahwa manajerial adalah kemampuan seseorang untuk bekerjasama dengan orang lain dalam proses perencanaan, pengorganisasian, pengarahan dan pengendalian usaha-usaha anggota organisasi dan penggunaan sumber daya organisasi lainnya agar mencapai tujuan organisasi yang telah ditetapkan secara efektif dan efisien.

\section{B. Kepala Sekolah}

Dinegara maju kepala sekolah mendapat sebutan bermacam-macam, sebagian menyebut kepala sekolah sebagai guru kepala (head teacher atau head master), kepala sekolah yang mengajar (teaching principle), kepala sekolah sebagai supervisor (supervising principle), director, dan pemimpin pendidikan (educational leadership). Penyebutan yang berbeda itu menurut macam disebabkan adanya kriteria yang mempersyaratkan kompetensi profesional kepala sekolah, kompetensi kepribadian kepala sekolah, kompetensi supervisi kepala sekolah, dan kompetensi manajerial kepala sekolah. Berikut ini salah satu bagan kepala sekolah berdasarkan peranannya : 


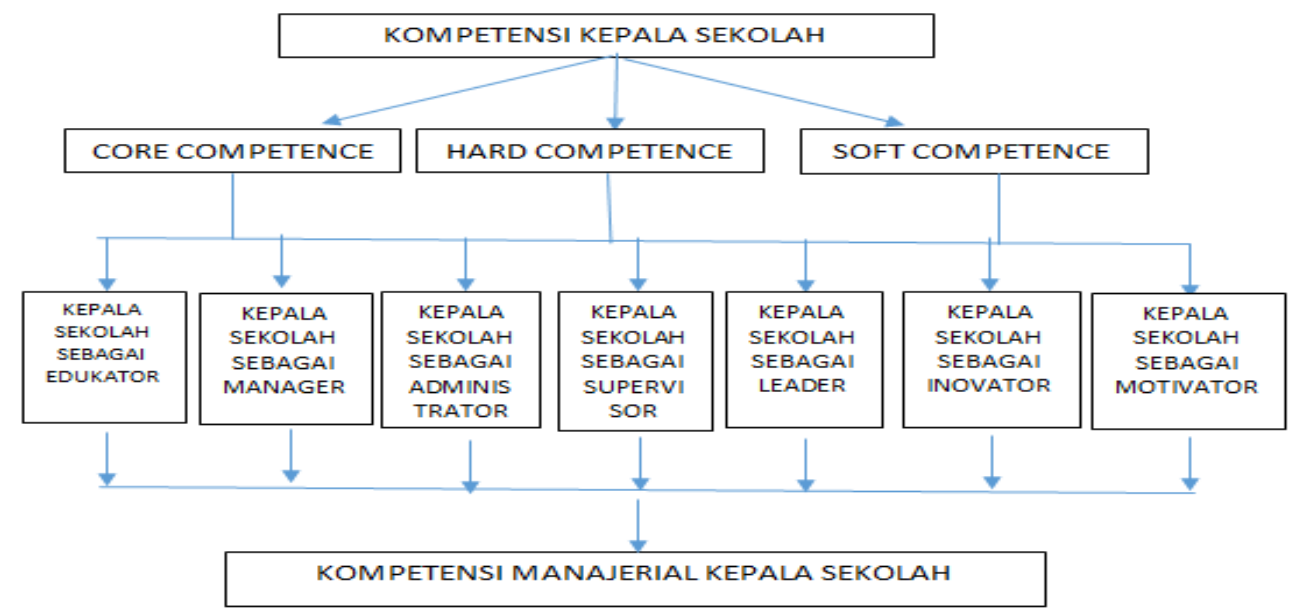

Gambar 1.1 - Peranan Kepala Sekolah

Gambar 1.1 menunjukkan kompetensi yang harus dimiliki oleh kepala sekolah berdasarkan peranannya. Dari beberapa uraian tentang defenisi manajerial dan kepala sekolah di atas dapat diambil suatu kesimpulan bahwa yang dimaksud manajerial kepala sekolah adalah kemampuan yang dimiliki oleh seorang guru yang diberi tugas tambahan sebagai kepala sekolah di Sekolah Menengah Kejuruan Negeri wilayah Kota Tangerang Selatan dalam proses perencanaan, pengorganisasian, pengarahan dan pengawasan usaha-usaha anggota organisasi dan penggunaan sumber-sumber daya organisasi lainnya agar mencapai tujuan organisasi yang telah ditetapkan, yaitu visi dan misi sekolah yang telah ditetapkan bersama dalam menciptakan sekolah efektif.

\section{METODOLOGI PENELITIAN}

\section{A. Tempat Penelitian}

Penelitian dilakukan pada Sekolah Menengah Kejuruan Negeri di wilayah Kota Tangerang Selatan, adapun daftar SMK Negeri tersebut adalah sebagai berikut :

Tabel 3.1 - Tabel SMK Negeri di Kota Tangerang Selatan

\begin{tabular}{|c|c|c|c|l|}
\hline No & NPSN & Nama Sekolah & Alamat Sekolah & Kepala Sekolah \\
\hline 1 & 20607836 & $\begin{array}{c}\text { SMK Negeri 1 Kota } \\
\text { Tangerang Selatan }\end{array}$ & $\begin{array}{c}\text { Jl. Raya Ciater Buana } \\
\text { Kencana Sektor 12 }\end{array}$ & Idris, S.Pd. M.Si. \\
\hline 2 & 20614730 & $\begin{array}{c}\text { SMK Negeri 2 Kota } \\
\text { Tangerang Selatan }\end{array}$ & $\begin{array}{c}\text { Jl. Pondok Aren Raya No. } \\
52\end{array}$ & $\begin{array}{l}\text { Drs. H. Ambiar, } \\
\text { M.Pd }\end{array}$ \\
\hline 3 & 20616038 & $\begin{array}{l}\text { SMK Negeri 3 Kota } \\
\text { Tangerang Selatan }\end{array}$ & $\begin{array}{c}\text { JL. Raya Puspiptek Perum } \\
\text { Puri Serpong I Ds. Setu K }\end{array}$ & $\begin{array}{l}\text { H. Abu Bakar, } \\
\text { S.Pd, MM. }\end{array}$ \\
\hline 4 & 69760703 & $\begin{array}{l}\text { SMK Negeri 4 Kota } \\
\text { Tangerang Selatan }\end{array}$ & $\begin{array}{c}\text { JL. Sumatra gg. Masjid Al- } \\
\text { huda. Rt.001 Rw.017 Rawa }\end{array}$ & $\begin{array}{l}\text { Dra. Angen } \\
\text { Sumijati }\end{array}$ \\
\hline 5 & 69757487 & $\begin{array}{l}\text { SMK Negeri 5 Kota } \\
\text { Tangerang Selatan }\end{array}$ & $\begin{array}{c}\text { Jl. Raya Pamulang 2 gg. } \\
\text { Benda Barat 7 No. 31 }\end{array}$ & $\begin{array}{l}\text { Rohmani Yusuf, S. } \\
\text { Pd, M. Pd }\end{array}$ \\
\hline 6 & 69939071 & $\begin{array}{l}\text { SMK Negeri 6 Kota } \\
\text { Tangerang Selatan }\end{array}$ & $\begin{array}{c}\text { JL. Griya Asri no. 7 } \\
\text { Mang }\end{array}$ & M. Akrom, M.Pd \\
\hline 7 & 69939073 & $\begin{array}{l}\text { SMK Negeri 7 Kota } \\
\text { Tangerang Selatan }\end{array}$ & $\begin{array}{c}\text { Jl. Cireundeu Raya No.2 } \\
\text { Ciputat Timur }\end{array}$ & Drs. Aceng Haruji \\
\hline
\end{tabular}




\section{B. Metode Penelitian}

Penelitian ini menggunakan metode kualitatif, karena beberapa pertimbangan, pertama menyesuaikan metode kualitatif lebih mudah apabila berhadapan dengan kenyaataan ganda; kedua, metode ini menyajikan secara langsung hakekat hubungan antara peneliti dan responden; ketiga, metode ini lebih peka dan lebih dapat menyesuaikan diri dengan penajaman pengaruh bersama dan terhadap pola-pola nilai yang dihadapi. Laporan penelitian akan berisi kutipan-kutipan data untuk memberi gambaran penyajian laporan tersebut. Data tersebut berasal dari naskah wawancara, catatan lapangan, videotape, dokumen pribadi, catatan atau memo dan dokumen resmi lainnya. Metode ini banyak memberikan konstribusi terhadap ilmu pengetahuan melalui pemberian informasi keadaan mutakhir, dan dapat membantu kita dalam mengidentifikasi faktor-faktor yang berguna untuk pelaksanaan percobaan. Selanjutnya metode ini dapat digunakan untuk menghasilkan suatu keadaan yang mungkin terdapat dalam situasi tertentu.

\section{Teknik Analisis dan SWOT Analisis}

\section{Teknik Analisis}

Dalam melakukan analisis terhadap berbagai data yang masuk, peneliti menggunakan (In Depth Interview), yaitu melakukan analisis dilakukan dengan cara wawancara mendalam dan komprehensif mengenai obyek penelitian, pertemuan dua orang bertukar informasi dengan dan ide melaluui tanya jawab sehingga dapat dikontruksikan makna dalam suatu topik tertentu, sehingga ditemukan kesenjangan nilai dan akan didapatkan perubahan-perubahan nilai manajerial. Untuk mempermudah pemahaman tersebut dibuatkan skema sebagai berikut :

\section{a. Model Identifikasi Nilai}

Dalam pengidentifikasian nilai-nilai, kepala sekolah dituntut untuk mengenal dan mengidentifikasi nilai-nilai yang berlaku saat ini. Kemudian diteruskan dengan mengenal dan mengidentifiikasi nilai-nilai yang diharapkan. Berikut ini bagan skema dari model identifikasi nilai :
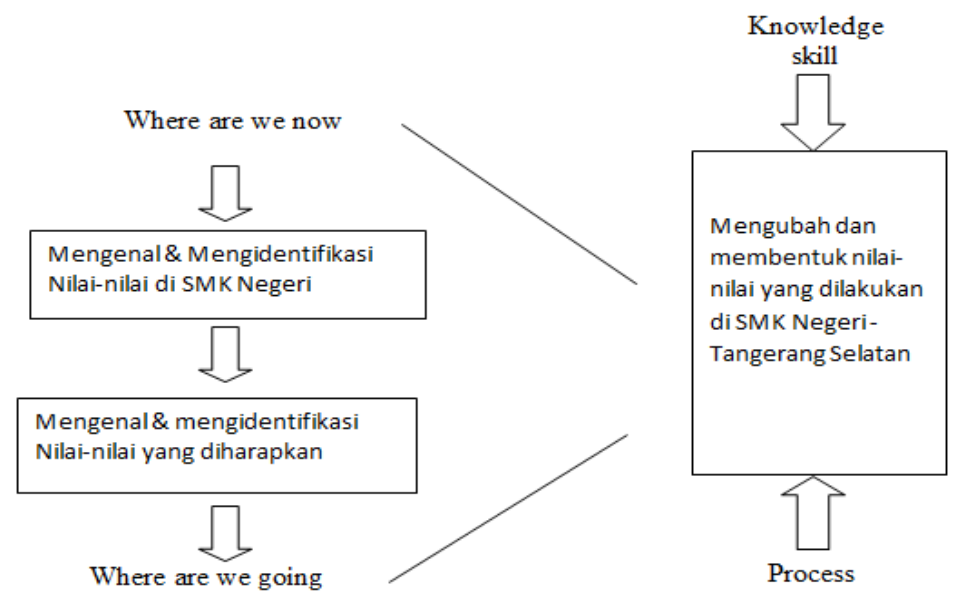

Gambar 2.1 - Model Indentifikasi Nilai 
Pada Gambar diatas merupakan skema yang mendasarkan pada pengetahuan (knowledge) dan ketrampilan (skill) serta semangat (desire), kepala sekolah mengubah dan membentuk habit melalui core process, pembuatan struktur, informasi yang jelas, keputusan yang tepat dan orang-orang yang baik yang berada dalam tim serta pemberian rewards sebagai bentuk apresiasi.

\section{b. Model Analisa Kesenjangan Nilai}

Dalam bagan di bawah ini kepala sekolah harus mampu memperpendek jarak atau kesenjangan antara nilai-nilai dengan filosofi Manajemen atau kebijakan yang dibuat oleh manajemen. Kemudian melakukan perbaikan dan perubahan dengan memperhatikan budaya sekolah (Mindseting) serta dengan menaksir sulitnya merubah budaya sekolah (Resistensi) dan dengan melakukan sinergi keduanya, sehingga makin dekatnya kesenjangan yang ada, maka diharapkan dapat menciptakan hasil berupa nilai-nilai baru yang dapat dijalankan.

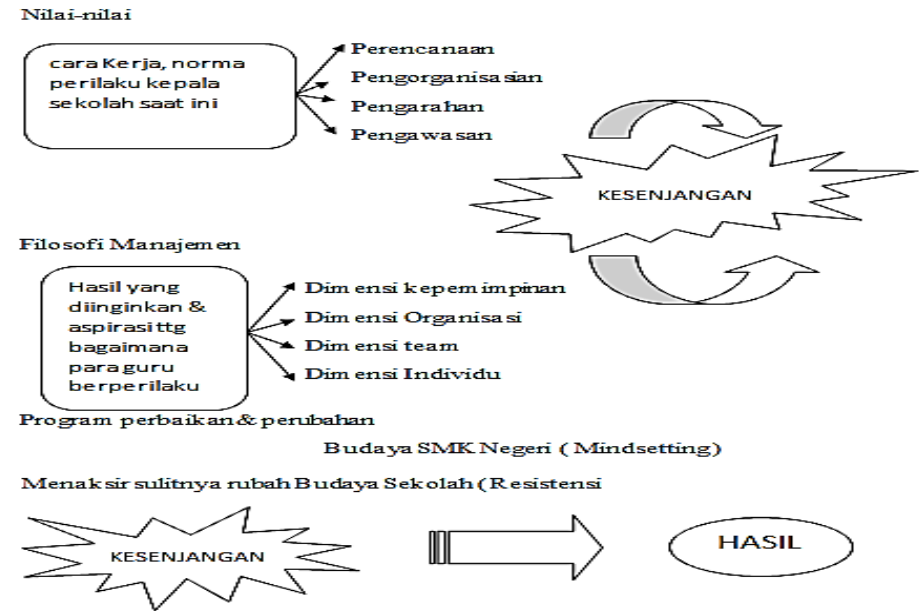

Gambar 2.2 - Model Analisa Kesenjangan Nilai

\section{c. Model Perubahan Melalui Pembentukan Nilai}

Eksistensi manusia senantiasa ada dalam relasi, maka pentingnya setiap orang berorganisasi. Dan dalam berorganbisasi tersebut seseorang dapat tumbuh dan berkembang. Pertumbuhan dan perkembangan manusia itu senantiasa ada dalam kerangka budaya. Dan saat munculnya kesenjangan antara budaya perusahaan dan budaya pekerja, maka dibutuhkan berbagai pendekatan untuk mengembangkan budaya perusahaan, sehingga berdaya guna bagi perusahaan atau manajemen menuju terciptanya kepemimpinan yang baik.

Ketiga model analisa tersebut sangat penting dipaparkan mengingat dinamika masyarakat yang terus bergerak yang menimbulkan dampak yang saling berkaitan terhadap berbagai aspek kehidupan.

Model yang ketiga ini merupakan sinergidarimodel pertama dan kedua yang dapat dijelaskan dalam Tabel 3.2 sebagai berikut : 
Tabel 3.2 : Model Perubahan melalui Pembentukan Nilai

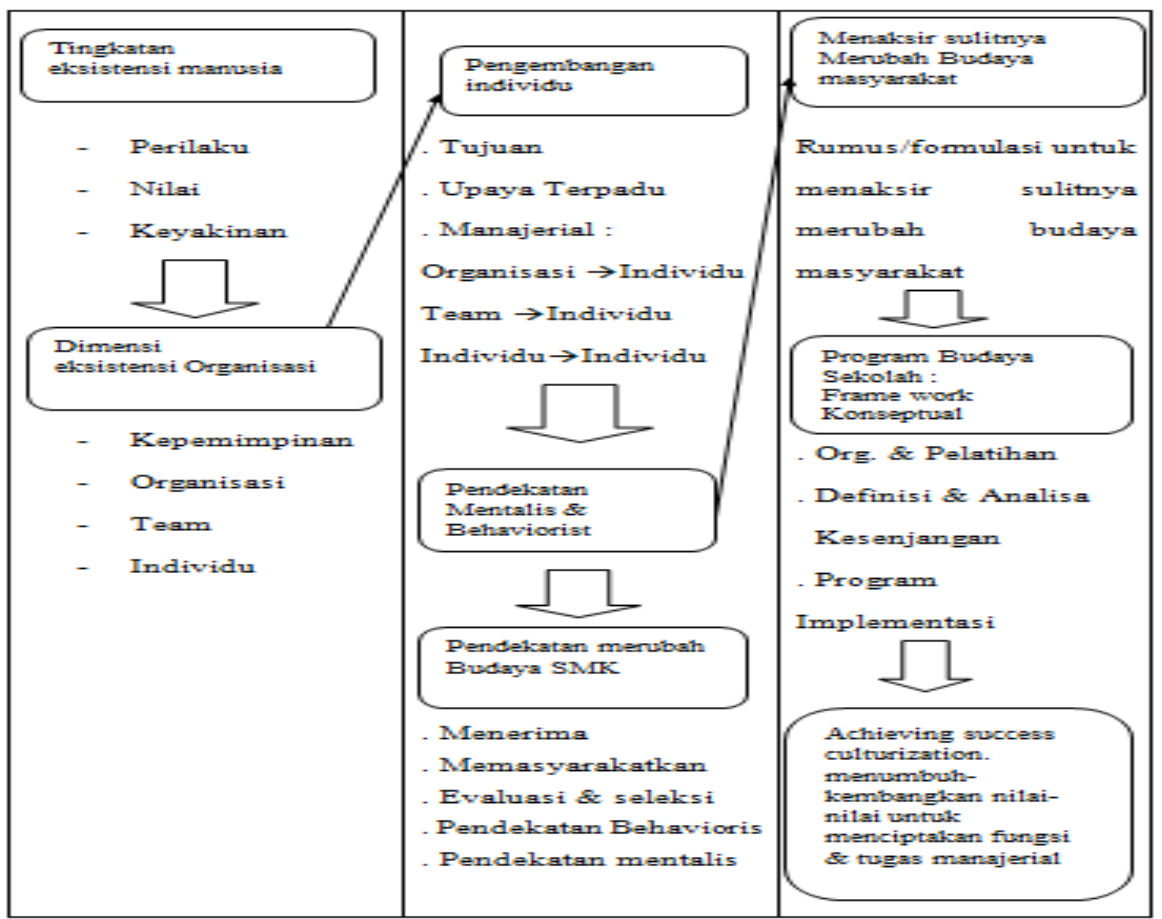

\section{SWOT Analisis}

Menurut Freddy Rangkuti Analis swot adalah indifikasi berbagai factor secara sistematis untuk merumuskan strategi perusahan. Analisis ini didasarkan pada logika yang dapat memaksimalkan kekuatan (sterngths) dan peluang (opportunities), namun secara bersamaan dapat meminimalkan kelemahan (weaknesses) dan ancaman (threats).

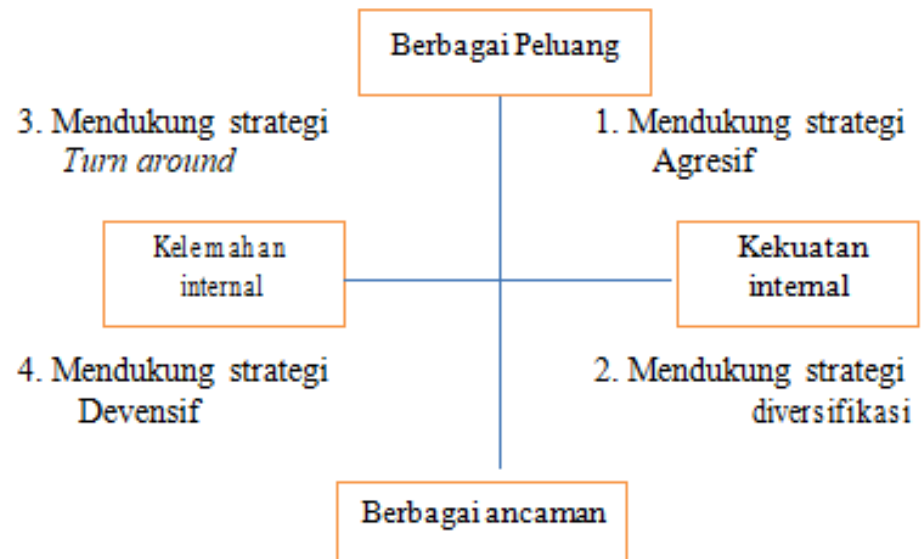

Gambar 2.3 - Analisis SWOT

Matrik yang digunakan dalam penelitian ini menggunakan matrik SWOT. Alat yang dipakai untuk menyususn faktor-faktor strategis perusahaan adalah Matrik SWOT. Matrik ini dapat mengambarkan secara jelas bagaimana peluang dan ancaman eksternal yang dihadapi perusahaan dapat disesuaikan dengan kekuatan dan kelemahan yang dimilki. Matrik ini dapat menghasilkan empat set kemungkinan alternative strategis 
Tabel 3.3 - Matrik SWOT

Tabel 3.4 Matrik SWOT

\begin{tabular}{|l|l|l|}
\hline EFAS & $\begin{array}{l}\text { STRENGTHS (S) } \\
\begin{array}{l}\text { Tentukan 5-10 faktor- } \\
\text { faktor kekuatan } \\
\text { Internal }\end{array}\end{array}$ & $\begin{array}{l}\text { WEAKNESSES(W) } \\
\begin{array}{l}\text { Tentukan 5-10 faktor- } \\
\text { faktor kelemahan } \\
\text { Internal }\end{array}\end{array}$ \\
\hline OPPORTUNIES $(\mathrm{O})$ & $\begin{array}{l}\text { STRATEGI SO } \\
\text { Ciptakan strategi } \\
\text { Tentukan5-10 faktor } \\
\text { peluang external } \\
\text { kekuatan untuk me- } \\
\text { manfaatkan peluang }\end{array}$ & $\begin{array}{l}\text { STRATEGI WO } \\
\text { Ciptakan strategi } \\
\text { yang meminimal-kan } \\
\text { kelelemahan untuk } \\
\text { memanfaatkan peluang }\end{array}$ \\
\hline $\begin{array}{l}\text { Tentukan5-10 } \\
\text { faktor ancaman } \\
\text { external }\end{array}$ & $\begin{array}{l}\text { STRATEGI(ST) } \\
\text { Ciptakan strategi } \\
\text { yang menggunakan } \\
\text { kekuatan untuk } \\
\text { mengatasi ancaman }\end{array}$ & $\begin{array}{l}\text { STRATEGI (WT) } \\
\text { Ciptakan strategi } \\
\text { yang meminimal-kan } \\
\text { kelelemahan untuk } \\
\text { mengatasi ancaman }\end{array}$ \\
\hline
\end{tabular}

Dari matrix diatas dapat dijabarkan bahwa terdapat empat strategi yaitu strategi SO, Strategi ST, Strategi WO, Strategi WT. Pada Strategi SO ini dibuat berdasarkan jalan pikiran perusahaan, yaitu dengan memanfaatkan seluruh kekuatan untuk merebut dan memanfaatkan peluang sebesar-besarnya. Pada strategi ST ini adalah strategi dalam menggunakan kekuatan dalam yang dimilki perusahaan untuk mengatasi ancaman. Sedangkan pada Strategi WO diterapkan berdasarkan pemanfaatan peluang yang ada dengan cara meminimalkan kelemahan yang ada dan pada Strategi WT ini didasarkan pada kegiatan yang bersifat defensive dan berusahan meminimalkan kelemahan yang adaserta menghindari ancaman.

\section{HASIL DAN PEMBAHASAN}

\section{A. Hasil Wawancara dan FGD (Forum Group Discussion)}

Dalam hal ini akan diuraikan terkait hasil wawancara yang dilakukan dari berbagai narasumber di tujuh Sekolah Menengah Kejuruan Negeri yang berada diwilayah Kota Tangerang Selatan yaitu SMKN 1, SMKN 2, SMKN 3, SMKN 4, SMKN 5, SMKN 6 dan SMKN 7, yang bertujuan untuk mengetahui kompetensi kepala sekolah dalam meningkatkan mutu sekolah. Subjek penelitian untuk wawancara adalah kepala sekolah dan wakil kepala sekolah. Sedangkan untuk Forum Grooup Discussion dilakukan bersama dengan kepala kompetensi keahlian, guru normatif, guru normatif, guru produktif dan siswa.

Peneliti melakukan FGD kepada guru-guru untuk memperoleh informasi terkait dnegan bagaimana manajerial kepala sekolah menengah kejuruan yang ada di wiliayah Kota Tangerang Selatan mempengaruhi mutu pendidikan. Guru guru yang dijadikan subjek penelitian sebanyak 42 guru, sedangkan untuk siswa sebanyak 14 orang, wakil kepala sekolah 35 orang, dan kepala kompetensi keahlian di masing-masing sekolah. Proses FGD dilakukan secara bersamaan pada massing masing sekolah. 
Berdasarkan temuan-temuan data penelitian sesuai dengan riil di lapangan yang diperoleh dari hasil wawancara mendalam dengan informan guna mendapatkan validasi data mengenai kompetensi manajerial kepala sekolah. Data yang dikumpulkan dari lapangan secara garis besar yaitu perencanaan, pengorganisasian, pengarahan, dan pengendalian dalam meningkatkan mutu sekolah.

\section{B. Menganalisis Data Studi Kasus}

\section{Strategi dalam Analisa Data}

Strategi yang digunakan dalam menganalisa data yakni dengan menggunakan analisa SWOT (Strenght, Weeknees, Opportunities, Threats).Strengtht (kekuatan) dan weakness (kelemahan), keduanya merupakan faktor internal dari SMK Negeri. Sedangkan Opportunities (peluang) dan Threats (Ancaman) merupakan faktor eksternal dari SMK Negeri.

a. Analisis Internal

Analisis faktor internal meliputi kekuatan dan kelemahan yang terjadi. Adapun analisa dalam strenght (kekuatan) meliputi :

1) Kapabilitas, yang dimiliki sangat bagus, baik dari sudut pengalaman kerja dan pengetahuan serta skill pemimpinnya.

2) Relationship yang dibangun sangat baik dengan berbagai komunitas

3) Manajemen Skill yang bagus, namun masih perlu pengembangan

4) Networking yang luas

5) Kepemimpinan organisasi dengan penguatan sampai di grassrootnya

Sedangkan untuk analisa kelemahan (weekness) meliputi :

1) Kurang optimalnya pemberdayaan potensi yang dimiliki serta tidak fokusnya kegiatan kerja menuju sasaran yang utama dari beberapa gurunya

2) Kapabilitas perlu terus dikembangkan

3) Fasilitas, sarana dan prasarana penunjang yang perlu terus ditingkatkan

b. Analisis Eksternal

Analisa faktor eksternal terdapat pada peluang (opportunity) dan ancaman (threat). Adapun analisa peluang (opportunity) meliputi:

1) Kemitraan dan Pengembangan pendidikan dengan berbagai sekolah

2) Kerjasama dengan lembaga-lembaga sebidang

3) Kerjasama dengan berbagai perusahaan dalam hal pengembangan teknologi

4) Eksplorasi potensi ke publik, terkait masalah manajerial kepala sekolah

Analisa ancaman (threat) diantaranya :

1) Makin banyak pendidkan sejenis (berbasis teknologi) yang dapat di akses lewat internet, sehingga memudahkan masyarakat mendapatkan kebutuhannya

2) Makin banyak munculnya tenaga pendidik baru dari bidang yang sama.

3) Perkembangan ilmu dan teknologi yang makin cepat yang harus diimbangi dengan penggalian kapasitas dan kapabilitas para pemimpin.

\section{Strategi Teknik Analisa Data}

Data-data tersebut dianalisa dan dinilai serta disinergikan untuk ditemukan rumusan strategi apa yang tepat. Seperti bagan di bawah ini : 
Tabel 4.1 : Strategi Teknik Analisa Data

\section{Kekuatan ( Faktor - faktor Inernal )}

1. Kapabilitas, yang dimiliki sangat bagus, baik dari sudut pengalaman kerja dan pengetahuan serta skill kepala sekolah dan para .guru dan teknik kependidikan

2. Relationship yang dibangun sangat baik dengan berbagai komunitas dunia usaha dan industri

3. Manajemen Skill yang berkualitas

4. Kepemimpinan kepala sekolah yang kuat

Peluang ( Faktor - faktor Eksternal )

1. Kemitraan dengan berbagai lembaga sejenis (pendidikan)

2. Kerjasama dengan lembaga-lembaga bidang pendidikan

3. Kerjasama dengan berbagai perusahaan dalam hal pengembangan manajerial

4. Eksplorasi potensi, terkait masalah manajemen
Kelemahan(Faktor - faktor Internal )

1. Kurang optimalnya pemberdayaan potensi yang dimiliki serta

2. tidak fokusnya kegiatan kerja menuju sasaran yang utama dari masing-masing guru

3. Kapasitas pendidikan perlu dikembangkan

4. Fasilitas, sarana dan prasarana penunjang yang perlu ditingkatkan

5. Waktu penyaluran dana BOS dan BOSDA yang memakan waktu lama

\section{Ancaman (Faktor- faktor Eksternal )}

1. Makin banyak institusi sejenis yang dapat di akses lewat internet, sehingga memudahkan masyarakat mendapatkan kebutuhannya dengan mudah dan murah.

2. Makin banyak munculnya tenaga kerja baru dalam garapan bidang yang sama

3. Perkembangan ilmu dan teknologi yang makin cepat yang harus diimbangi dengan penggalian kapasitas dan kapabilitas kepala sekolah dan pendidik

4. Lingkungan tidak menyetujui perkembangan sekolah

Langkah selanjutnya yang ditempuh setelah proses pembuatan daftar indikator dari variabel lingkungan internal dan eksternal, serta memformulasikan ke dalam strategi SO, S-T, W-O dan W-T adalah memberian bobot (weight) pada masing-masing indikator yaitu dengan cara membandingkan peran satu indikator tertentu dengan indikator lainnya. Bobot maksimum yang diberikan pada setiap kategori adalah 1 atau $100 \%$. Bobot maksimum tersebut kemudian didistribusikan ke semua indikator, yaitu seperti tabel di bawah ini :

Tabel 4.2 : Tabel Indikator Bobot 4 Kuadran

\begin{tabular}{|c|l|c|}
\hline NO & \multicolumn{1}{|c|}{ INDIKATOR } & BOBOT \\
\hline 1 & STRENGHT & 1.00 \\
\hline & a. Kapabilitas, yang dimiliki sangat bagus, baik dari sudut pengalaman & 0,20 \\
& berja, dan pengetahuan serta skill kepala sekolah & \\
& b. Relationship yang dibangun sangat baik dengan berbagai lembaga & 0,20 \\
& c. Manajemen Skill yang bagus & 0,20 \\
& d. Networking yang luas & 0,20 \\
& e. Leadership & 0,20 \\
\hline 2 & WEAKNESS & 1,00 \\
& a. Kurang optimalnya pemberdayaan potensi yang dimiliki & 0,20 \\
& b. Tidak fokusnya kegiatan kerja menuju sasaran yang utama dari & 0,20 \\
& c. Kapasitas pendidikan perlu dikembangkan & 0,20 \\
& d. Fasilitas, sarana dan prasarana penunjang yang perlu ditingkatkan & 0,20 \\
& e. Waktu penyaluran dana BOS dan BOSDA yang memakan waktu lama & 0,20 \\
\hline 3 & OPPORTUNITY & 1.00 \\
\hline & a. Kemitraan dan Pengembangan pendidikan & 0,25 \\
& b. Kerjasama dengan lembaga-lembaga pendidikan & 0,25 \\
& c. Kerjasama pengembangan pendidikan dengan berbagai perusahaan & 0,25 \\
& d. Eksplorasi potensi ke publik, terkait masalah manajerial & 0,25 \\
\hline
\end{tabular}




\begin{tabular}{|c|c|c|}
\hline 4 & THREAT & 1.00 \\
\hline \multirow{1}{*}{ a. Makin banyak perusahaan sejenis (pendidikan) yang dapat di akses } & 0,25 \\
& $\begin{array}{l}\text { lewat internet, sehingga memudahkan masyarakat mendapatkan } \\
\text { kebutuhannya dengan mudah }\end{array}$ & \\
& b. Makin banyak munculnya tenaga kerja ( pendidik) baru & 0,25 \\
& c. Perkembangan ilmu dan teknologi yang makin cepat yang harus & 0,25 \\
& diimbangi dengan penggalian kapasitas dan kapabilitas sekolah. & 0,25 \\
\hline
\end{tabular}

Setelah bobot masing-masing indikator ditentukan, selanjutnya memberikan penilaian terhadap besar kecilnya sumbangan atau hambatan yang diberikan oleh masing-masing indikator terhadap pencapaian tujuannya, khususnya untuk satu periode penyusunan rencana strategis. Penilaian ini dilakukan dengan memberikan skor dari 1 sampai 4 . Berikut tabel total skor masing-masing indikator :

Tabel 4.3 : Total skor masing-masing indikator

\begin{tabular}{|c|c|c|}
\hline NO & INDIKATOR & Rating \\
\hline \multirow[t]{6}{*}{1} & Strength & \\
\hline & $\begin{array}{l}\text { 1. Kapabilitas, yang dimiliki sangat bagus, baik dari sudut pengalaman kerja } \\
\text { dan pengetahuan serta skill para pendidik. }\end{array}$ & 4 \\
\hline & 2. Relationship yang dibangun sangat baik dengan berbagai komunitas & 4 \\
\hline & 3. Manajemen Skill yang bagus & 3 \\
\hline & 4. Networking yang luas & 4 \\
\hline & 5. Leadership & 4 \\
\hline \multirow[t]{6}{*}{2} & Weakness & \\
\hline & 1. Kurang optimalnya pemberdayaan potensi yang dimiliki & 2 \\
\hline & 2. Tidak fokusnya kegiatan menuju sasaran yang utama para pendidik / guru & 1 \\
\hline & 3. Kapasitas pendidikan kepsek dan guru perlu di upgrade & 2 \\
\hline & 4. Fasilitas, sarana dan prasarana penunjang & 1 \\
\hline & 5. Waktu penyaluran dana BOS dan BOSDA yang memakan waktu lama & 1 \\
\hline \multirow[t]{5}{*}{3} & Opportunity & \\
\hline & 1. Kemitraan dan Pengembangan SDM di berbagai komunitas & 4 \\
\hline & 2. Kerjasama dengan lembaga-lembaga pendidkan & 3 \\
\hline & 3. Kerjasama pengembangan manajemen dengan berbagai perusahaan & 4 \\
\hline & 4. Eksplorasi potensi ke publik, terkait dengan manajemen & 4 \\
\hline \multirow[t]{5}{*}{4} & Threat & \\
\hline & $\begin{array}{l}\text { 1. Makin banyak institusi sejenis (pendidikan) yang dapat di akses lewat } \\
\text { internet, sehingga memudahkan masyarakat mendapatkan kebutuhannya } \\
\text { dengan mudah }\end{array}$ & 2 \\
\hline & 2. Makin banyaknya muncul tenaga guru/pendidik baru yang berkualitas & 1 \\
\hline & $\begin{array}{l}\text { 3. Perkembangan ilmu dan teknologi yang makin cepat yang harusdiimbangi } \\
\text { dengan penggalian kapasitas dan kapabilitas. }\end{array}$ & 2 \\
\hline & 4. Lingkungan tidak menyetujui perkembangan sekolah & 2 \\
\hline
\end{tabular}

Tahapan setelah menentukan skor atau nilai masing-masing indikator adalah menghitung nilai tertimbang IFAS dan EFAS, seperti pada Tabel 4.4. dan Tabel 4.5

Tabel 4.4 : Nilai Tertimbang IFAS

\begin{tabular}{|l|l|l|l|c|}
\hline No & Indikator & Bobot & Skor & $\begin{array}{c}\text { Nilai } \\
\text { Tertimbang }\end{array}$ \\
\hline 1. & Strength & & & \\
\hline
\end{tabular}




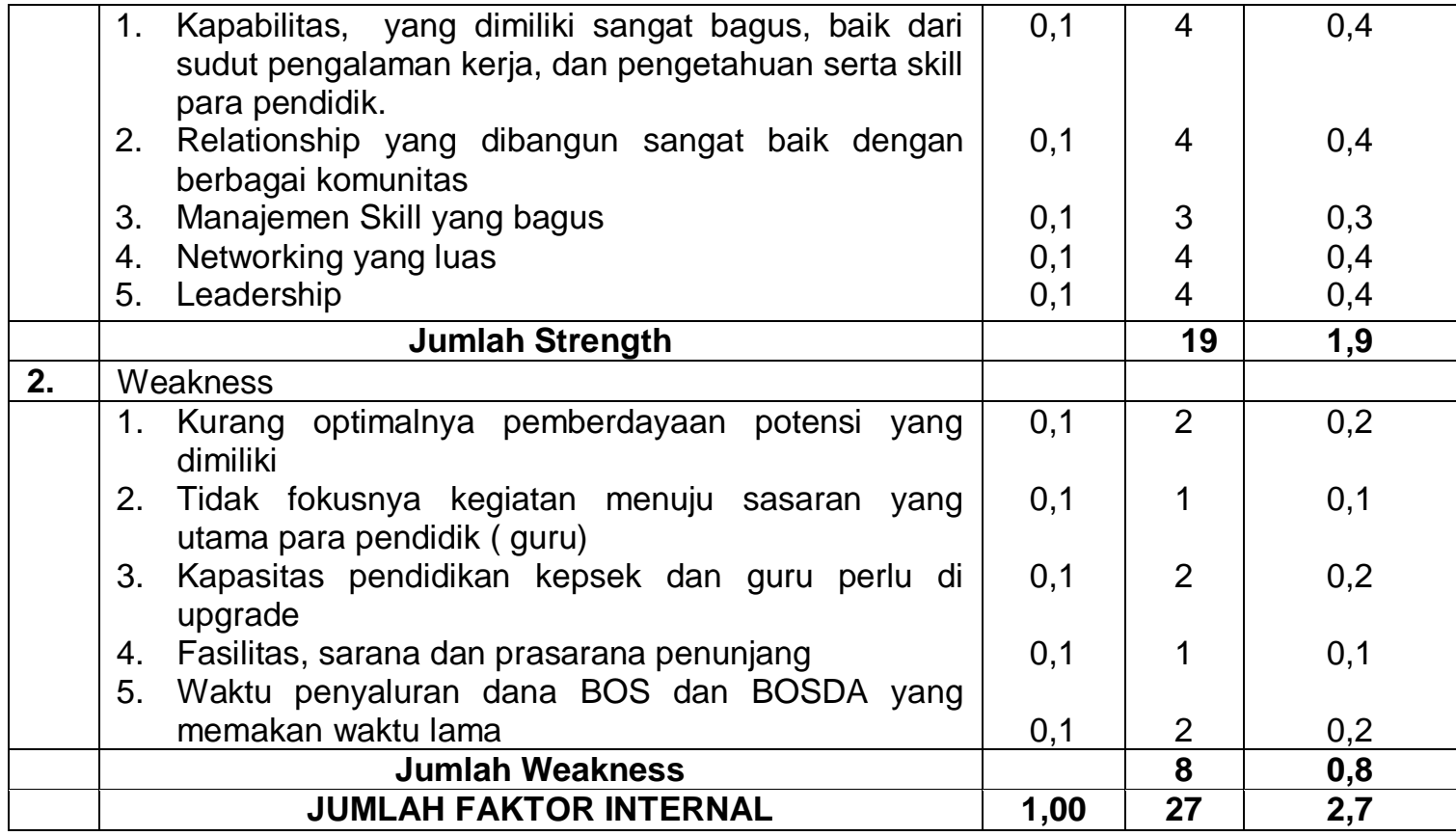

Tabel 4.5: Nilai Tertimbang EFAS

\begin{tabular}{|c|c|c|c|c|}
\hline No & Indikator & Bobot & Skor & $\begin{array}{c}\text { Nilai } \\
\text { Tertimbang }\end{array}$ \\
\hline \multirow[t]{6}{*}{1.} & Opportunity & & & \\
\hline & $\begin{array}{l}\text { 1. Kemitraan dan Pengembangan SDM di berbagai } \\
\text { komunitas }\end{array}$ & 0,125 & 4 & 0,5 \\
\hline & 2. Kerjasama dengan lembaga-lembaga pendidkan & 0,125 & 3 & 0,375 \\
\hline & $\begin{array}{l}\text { 3. Kerjasama dengan berbagai perusahaan dalam hal } \\
\text { pengembangan manajemen }\end{array}$ & 0,125 & 4 & 0,5 \\
\hline & $\begin{array}{l}\text { 4. Eksplorasi potensi ke publik, terkait dengan } \\
\text { manajemen }\end{array}$ & 0,125 & 4 & 0,5 \\
\hline & Jumlah Strength & & 19 & 1,875 \\
\hline \multirow[t]{7}{*}{2.} & Threat & & & \\
\hline & $\begin{array}{l}\text { 1. Makin banyak institusi sejenis (pendidikan) yang } \\
\text { dapat di akses lewat internet, sehingga } \\
\text { memudahkan masyarakat mendapatkan } \\
\text { kebutuhannya dengan mudah }\end{array}$ & 0,125 & 2 & 0,25 \\
\hline & $\begin{array}{l}\text { 2. Makin banyaknya muncul tenaga guru/pendidik baru } \\
\text { yang kurang berkualitas }\end{array}$ & 0,125 & 1 & 0,125 \\
\hline & $\begin{array}{l}\text { 3. Perkembangan ilmu dan teknologi yang makin cepat } \\
\text { yang harusdiimbangi dengan penggalian kapasitas } \\
\text { dan kapabilitas. }\end{array}$ & 0,125 & 2 & 0,25 \\
\hline & 4. Lingkungan tidak menyetujui perkembangan sekolah & 0,125 & 2 & 0,25 \\
\hline & Jumlah Weakness & & 9 & 0,875 \\
\hline & JUMLAH FAKTOR EXTERNAL & 1,00 & 28 & 2,75 \\
\hline
\end{tabular}

Berdasarkan hasil penelitian disarankan agar pihak sekolah melaksanakan RKAS (Rencana Kegiatan Anggaran Sekolah) yang telah disusun bersama-sama dengan seluruh stakeholder sekolah. Atau dapat juga dilihat pada strategi SWOT dibawah ini :

Tabel 4.6 : Strategi matrik SWOT

\begin{tabular}{|l|l|l|}
\hline INTERNAL FACTOR & $\begin{array}{l}\text { STRENGTH } \\
\text { a. Kapabilitas, yang dimiliki } \\
\text { sangat bagus, baik dari sudut }\end{array}$ & $\begin{array}{l}\text { WEAKNESS } \\
\text { a. Kurang } \\
\text { pemberdayaan potimalnya } \\
\text { petensi }\end{array}$ \\
\hline
\end{tabular}




\begin{tabular}{|c|c|c|}
\hline $\begin{array}{l}\text { EXTERNAL } \\
\text { FACTOR }\end{array}$ & 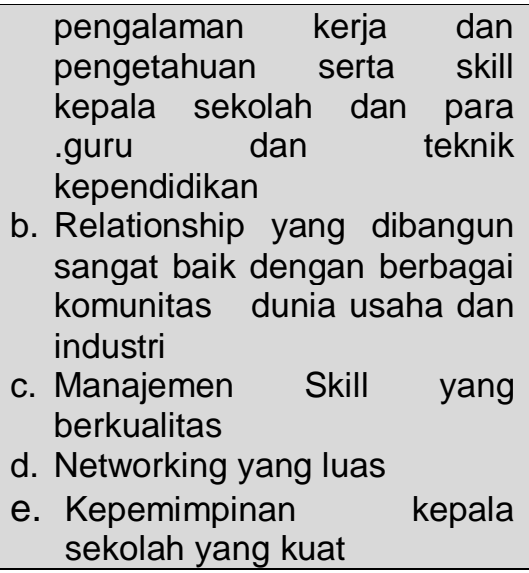 & $\begin{array}{l}\text { yang dimiliki serta } \\
\text { b. tidak fokusnya kegiatan } \\
\text { kerja menuju sasaran } \\
\text { yang utama dari masing- } \\
\text { masing guru } \\
\text { c. Kapasitas pendidikan } \\
\text { perlu dikembangkan } \\
\text { d. Fasilitas, sarana dan } \\
\text { prasarana penunjang } \\
\text { yang perlu ditingkatkan } \\
\text { e. Waktu penyaluran dana } \\
\text { BOS dan BOSDA yang } \\
\text { memakan waktu lama }\end{array}$ \\
\hline $\begin{array}{l}\text { OPPORTUNITIES } \\
\text { Kemitraan }\end{array}$ & $\searrow$ STRATEGI S-O & $\nabla$ STRATEGI W-O \\
\hline $\begin{array}{l}\text { Pengembangan SDM di } \\
\text { berbagai lembaga } \\
\text { pendidikan dengan } \\
\text { Kerjasama dengan } \\
\text { lembaga-lembaga } \\
\text { pendidikan } \\
\text { Kerjasama potensi, } \\
\text { berbagai lembaga dalam } \\
\text { hal pengembangan } \\
\text { manajerial } \\
\text { Eksplorasi potaienen } \\
\text { terkait manajemen }\end{array}$ & $\begin{array}{l}\text { Mejalin kerjasama / MOU } \\
\text { dengan lembaga pengem- } \\
\text { bangan pendidikan dan } \\
\text { Manajerial } \\
\text { Promosi dan marketing } \\
\text { terhadap Branding yang } \\
\text { dimiliki SMK Negeri } \\
\text { Menambah referensi-refernsi } \\
\text { baru, penggalian pengetahuan } \\
\text { /teori yang yang terkini/ } \\
\text { Konsultan pendidikan }\end{array}$ & $\begin{array}{l}\text { - Menambah perluasan } \\
\text { pengelolaan SDM untuk } \\
\text { mendukung strategi S-O } \\
\text { - Membuat sarana dan } \\
\text { prasarana guna } \\
\text { mendukung pengembang- } \\
\text { an manajerial }\end{array}$ \\
\hline $\begin{array}{l}\text { THREAT } \\
\text { 1. Makin banyak lembaga } \\
\text { sejenis yang dapat di } \\
\text { akses lewat internet. } \\
\text { 2. Makin banyak tenaga } \\
\text { kerja baru } \\
\text { 3. Perlunya penggalian ka- } \\
\text { pasitas dan kapabi-litas. } \\
\text { 4. Lingkungan tidak menye- } \\
\text { tujui perkembangan } \\
\text { sekolah }\end{array}$ & $\begin{array}{l}\text { STRATEGI S-T } \\
\text { - Menjalin net-working dan } \\
\text { relationship pasca pelatihan/ } \\
\text { kegiatan. } \\
\text { - Menambah fitur-fitur dengan } \\
\text { memberikan kelebihan- } \\
\text { kelebihan. } \\
\text { - Fokus pada satu kegiatan } \\
\text { dengan kualitas dan } \\
\text { pelayanan yang kompetitif }\end{array}$ & $\begin{array}{l}\text { - Membuat program promosi } \\
\text { untuk meraih pelanggan } \\
\text { yang lebih banyak. } \\
\text { - Kerjasama dengan banyak } \\
\text { Event Organizer untuk } \\
\text { membuat program pe- } \\
\text { ngembangan SDM }\end{array}$ \\
\hline
\end{tabular}

Berdasarkan analisis deskriptif dan tabel pengukuran respon digunakan untuk menjawab proposisi sebagai berikut :

1. Untuk menjawab proposisi pertama mengenai kompetensi manajerial kepala sekolah menengah kejuruan negeri di Kota Tangerang Selatan untuk meningkatkan mutu sekolah saat ini dapat terlihat dari hasil questioner berikut :

Tabel 4.7 : Hasil Kuisioner

\begin{tabular}{|c|c|c|c|c|c|c|c|c|c|c|}
\hline \multirow{2}{*}{$\begin{array}{l}\mathbf{N} \\
\mathbf{0}\end{array}$} & \multirow[b]{2}{*}{ Pertanyaan } & \multicolumn{5}{|c|}{ TANGGAPAN } & \multirow{3}{*}{ Sampel } & \multirow{3}{*}{$\begin{array}{l}\text { Skor } \\
\text { total }\end{array}$} & \multirow{3}{*}{$\begin{array}{l}\text { Rata- } \\
\text { rata } \\
\text { Skor }\end{array}$} & \multirow[b]{2}{*}{ Ket } \\
\hline & & SS & S & KS & TS & STS & & & & \\
\hline & Perencanaan & & & & & & & & & \\
\hline 1 & $\begin{array}{l}\text { Kepala sekolah } \\
\text { merumuskan misi dan } \\
\text { tujuan sekolah secara } \\
\text { jelas }\end{array}$ & 99 & 64 & 19 & 18 & & 200 & 844 & 4.22 & SB \\
\hline 2 & Kepala sekolah & 96 & 67 & 21 & 16 & & 200 & 843 & 4.215 & SB \\
\hline
\end{tabular}


JURNAL ILMIAH ILMU MANAJEMEN

\begin{tabular}{|c|c|c|c|c|c|c|c|c|c|}
\hline & $\begin{array}{lr}\text { merumuskan dan } \\
\text { meneliti pekerjaan- } \\
\text { pekerjaan yang akan } \\
\text { dilaksanakan } & \text { oleh } \\
\text { seluruh personil } & \end{array}$ & & & & & & & & \\
\hline 3 & $\begin{array}{l}\text { Kepala sekolah } \\
\text { menentu-kan langkah- } \\
\text { langkah stra-tegis } \\
\text { untuk mencapai misi } \\
\text { dan tujuan sekolah }\end{array}$ & 102 & 61 & 21 & 16 & 200 & 849 & 4.245 & SB \\
\hline 4 & $\begin{array}{l}\text { Kepala sekolah } \\
\text { menentukan rencana } \\
\text { tahunan sekolah yang } \\
\text { mencakup epegawaian } \\
\text { dan perlengkapan } \\
\text { sekolah }\end{array}$ & 92 & 71 & 24 & 13 & 200 & 842 & 4.21 & SB \\
\hline 5 & $\begin{array}{l}\text { Kepala sekolah } \\
\text { menganalisis faktor- } \\
\text { faktor kekuatan, } \\
\text { kelemahan, peluang } \\
\text { dan ancaman yang } \\
\text { dihadapi sekolah }\end{array}$ & 99 & 64 & 21 & 16 & 200 & 846 & 4.23 & SB \\
\hline \multicolumn{8}{|c|}{ Rata Rata } & 4.224 & SB \\
\hline \multicolumn{10}{|c|}{ Pengorganisasian } \\
\hline 6 & $\begin{array}{lr}\text { Kepala } & \text { sekolah } \\
\text { membuat } & \text { struktur } \\
\text { organisasi sekolah } \\
\text { yang efektif dan } \\
\text { efisien }\end{array}$ & 98 & 65 & 21 & 19 & 200 & 845 & 4.225 & SB \\
\hline 7 & $\begin{array}{l}\text { Kepala sekolah } \\
\text { memberikan tugas } \\
\text { mengajar kepada guru } \\
\text { sesuai dengan latar } \\
\text { belakang pendidikan } \\
\text { yang dimilikinya }\end{array}$ & 93 & 70 & 20 & 17 & 200 & 839 & 4.195 & SB \\
\hline 8 & $\begin{array}{lr}\text { Kepala } & \text { sekolah } \\
\text { menyusun } & \text { rincian } \\
\text { tugas setiap personil } & \text { sekolah secara jelas } \\
\end{array}$ & 93 & 69 & 22 & 16 & 200 & 839 & 4.195 & SB \\
\hline 9 & $\begin{array}{l}\text { Kepala sekolah dapat } \\
\text { mengoptimalkan hari- } \\
\text { hari efektif belajar } \\
\text { untuk kegiatan belajar } \\
\text { mengajar }\end{array}$ & 93 & 70 & 20 & 17 & 200 & 839 & 4.195 & SB \\
\hline 10 & $\begin{array}{l}\text { Kepala sekolah } \\
\text { mengembangkan } \\
\text { metode/cara mengajar } \\
\text { siswa }\end{array}$ & 96 & 66 & 21 & 17 & 200 & 841 & 4.205 & SB \\
\hline 11 & $\begin{array}{l}\text { Kepala sekolah } \\
\text { mengembangkan } \\
\text { program pengajaran } \\
\text { perbaikan bagi para } \\
\text { siswa yang belum } \\
\text { mencapai ketuntasan } \\
\text { belajar }\end{array}$ & 94 & 69 & 20 & 7 & 200 & 840 & 4.2 & SB \\
\hline 12 & Kepala sekolah & 92 & 71 & 20 & 17 & 200 & 838 & 4.19 & SB \\
\hline
\end{tabular}


IURNAL ILMIAH ILMU MANAJEMEN

\begin{tabular}{|c|c|c|c|c|c|c|c|c|c|c|}
\hline & $\begin{array}{l}\text { mengembangkan } \\
\text { programprogram } \\
\text { ekstra kulikuliler yang } \\
\text { berwawasan } \\
\text { keunggulan }\end{array}$ & & & & & & & & & \\
\hline \multicolumn{9}{|c|}{ Rata Rata } & 4.197 & $\mathrm{SB}$ \\
\hline \multicolumn{11}{|c|}{ Pengarahan } \\
\hline 13 & $\begin{array}{lr}\text { Kepala } & \text { sekolah } \\
\text { memberikan } & \text { saran, } \\
\text { masukan dan } & \text { sugesti } \\
\text { kepada seluruh } & \text { personil sekolah }\end{array}$ & 104 & 59 & 24 & 13 & & 200 & 854 & 4.27 & SB \\
\hline 14 & $\begin{array}{l}\text { Kepala sekolah mem- } \\
\text { bangkitkan semangat } \\
\text { kerja seluruh personil } \\
\text { sekolah }\end{array}$ & 95 & 68 & 21 & 16 & & 200 & 842 & 4.21 & SB \\
\hline 15 & $\begin{array}{lc}\text { Kepala } & \text { sekolah } \\
\text { menjadi } & \text { sumber } \\
\text { inspirasi } & \text { untuk } \\
\text { kemajuan sekolah }\end{array}$ & 99 & 64 & 22 & 15 & & 200 & 847 & 4.235 & SB \\
\hline 16 & $\begin{array}{l}\text { Kepala sekolah } \\
\text { memberi-kan } \\
\text { bimbingan dan arahan } \\
\text { secara berkala kepada } \\
\text { seluruh personil } \\
\text { sekolah }\end{array}$ & 103 & 58 & 23 & 16 & & 200 & 848 & 4.24 & SB \\
\hline 17 & 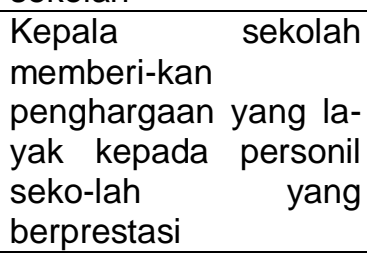 & 97 & 62 & 26 & 15 & & 200 & 841 & 4.205 & SB \\
\hline 18 & $\begin{array}{l}\text { Kepala sekolah } \\
\text { memberi-kan sanksi } \\
\text { atau hukuman yang } \\
\text { tegas kepada perso-nil } \\
\text { sekolah yang melang- } \\
\text { gar aturan }\end{array}$ & 97 & 66 & 21 & 16 & & 200 & 844 & 4.22 & SB \\
\hline 19 & $\begin{array}{l}\text { Kepala sekolah } \\
\text { memiliki kepribadian } \\
\text { yang patut dicontoh } \\
\text { oleh seluruh elemen } \\
\text { sekolah }\end{array}$ & 100 & 63 & 20 & 14 & & 200 & 846 & 4.23 & SB \\
\hline 20 & $\begin{array}{lr}\text { Kepala } & \text { sekolah } \\
\text { memiliki pengalaman } \\
\text { yang luas tentang } \\
\text { dunia sekolah }\end{array}$ & 93 & 70 & 24 & 13 & & 200 & 843 & 4.215 & SB \\
\hline 21 & $\begin{array}{lr}\text { Kepala } & \text { sekolah } \\
\text { memaha-mi } & \text { tugas- } \\
\text { tugas apa } & \text { saja yang } \\
\text { harus } & \text { dikerjakan } \\
\text { olehnya } & \end{array}$ & 97 & 66 & 23 & 14 & & 200 & 846 & 4.23 & SB \\
\hline 22 & $\begin{array}{l}\text { Kepala sekolah } \\
\text { memaha-mi keinginan } \\
\text { bawahan (guru, staf } \\
\text { dan para siswa) }\end{array}$ & 94 & 67 & 21 & 17 & 1 & 200 & 8.36 & 4.18 & SB \\
\hline
\end{tabular}


JURNAL ILMIAH ILMU MANAJEMEN

\begin{tabular}{|c|c|c|c|c|c|c|c|c|c|}
\hline 23 & $\begin{array}{lr}\text { Kepala } & \text { sekolah } \\
\text { memaha-mi } & \text { iklim } \\
\text { organisasi } & \text { yang } \\
\text { dibawahinya. } & \\
\end{array}$ & 100 & 63 & 21 & 16 & 200 & 847 & 4.235 & SB \\
\hline 24 & $\begin{array}{lr}\text { Kepala } & \text { sekolah } \\
\text { memposisikan dirinya } \\
\text { sebagai se-orang } \\
\text { pemimpin sekolah. }\end{array}$ & 102 & 61 & 19 & 18 & 200 & 847 & 4.235 & SB \\
\hline 25 & $\begin{array}{l}\text { Kepala sekolah } \\
\text { memaha-mi segala } \\
\text { keputusan/ke-bijakan } \\
\text { yang diambil yang } \\
\text { berkaitan dengan } \\
\text { sekolah }\end{array}$ & 96 & 67 & 22 & 15 & 200 & 844 & 4.22 & SB \\
\hline 26 & $\begin{array}{l}\text { Memahami tugas- } \\
\text { tugas apa saja yang } \\
\text { harus dikerjakan oleh } \\
\text { tiap-tiap personil } \\
\text { sekolah }\end{array}$ & 96 & 67 & 20 & 17 & 200 & 842 & 4.21 & SB \\
\hline 27 & $\begin{array}{l}\text { Wakil kepala sekolah } \\
\text { mengambil keputusan } \\
\text { sendiri ketika kepala } \\
\text { sekolah tidak ada di } \\
\text { sekolah }\end{array}$ & 100 & 60 & 20 & 20 & 200 & 840 & 4.2 & SB \\
\hline \multicolumn{8}{|c|}{ Rata Rata } & 4.22 & SB \\
\hline \multicolumn{10}{|c|}{ Pengawasan } \\
\hline 28 & $\begin{array}{l}\text { Kepala sekolah } \\
\text { meluang-kan waktu } \\
\text { untuk mengerjakan } \\
\text { tugas diluar tugas } \\
\text { sebagai kep. sekolah }\end{array}$ & 99 & 63 & 20 & 18 & 200 & 843 & 4.215 & SB \\
\hline 29 & $\begin{array}{l}\text { Kepala sekolah } \\
\text { menjadi contoh / suri } \\
\text { tauladan yang baik } \\
\text { bagi seluruh personil } \\
\text { sekolah }\end{array}$ & 101 & 62 & 19 & 18 & 200 & 846 & 4.23 & SB \\
\hline 30 & $\begin{array}{l}\text { Kepala sekolah } \\
\text { menyampaikan } \\
\text { Informasi tentang } \\
\text { berbagai kemajuan } \\
\text { dan } \quad \text { prestasi } \\
\text { madarasah kepada } \\
\text { masyarakat luas } \\
\end{array}$ & 97 & 66 & 19 & 18 & 200 & 842 & 4.21 & SB \\
\hline 31 & $\begin{array}{l}\text { Kepala sekolah } \\
\text { menyam-paikan } \\
\text { informasi tentang } \\
\text { berbagai kendala } \\
\text { atau masalah yang } \\
\text { terjadi di sekolah }\end{array}$ & 101 & 62 & 22 & 15 & 200 & 849 & 4.245 & SB \\
\hline 32 & $\begin{array}{lr}\text { Kepala } & \text { sekolah } \\
\text { bermusya-warah } \\
\text { dengan } & \text { elemen } \\
\text { elemen sekolah untuk } \\
\text { mencari } & \text { solusi dari } \\
\text { masalah } & \text { yang } \\
\text { dihadapi } & \\
\end{array}$ & 92 & 71 & 19 & 18 & 200 & 837 & 4.185 & SB \\
\hline
\end{tabular}




\begin{tabular}{|c|c|c|c|c|c|c|c|c|c|}
\hline 33 & $\begin{array}{l}\text { Kepala sekolah } \\
\text { memiliki ide-ide dan } \\
\text { kreasi-kreasi untuk } \\
\text { kemajuan sekolah }\end{array}$ & 102 & 61 & 26 & 11 & 200 & 854 & 4027 & SB \\
\hline 34 & $\begin{array}{l}\text { Kepala sekolah } \\
\text { merumus-kan kriteria- } \\
\text { kriteria keber-hasilan } \\
\text { program sekolah }\end{array}$ & 96 & 67 & 23 & 14 & 200 & 845 & 4.225 & SB \\
\hline 35 & $\begin{array}{l}\text { Kepala sekolah } \\
\text { merumus-kan } \\
\text { indikator-indikator } \\
\text { untuk mengukur } \\
\text { keberha-silan } \\
\text { program sekolah }\end{array}$ & 98 & 66 & 24 & 12 & 200 & 850 & 4.25 & SB \\
\hline 36 & $\begin{array}{lr}\text { Kepala } & \text { sekolah } \\
\text { mengakui } & \text { dan } \\
\text { menghargai } & \text { setiap } \\
\text { prestasi } & \text { yang } \\
\text { dihasilkan oleh } & \text { staf, } \\
\text { guru, ataupun } & \text { para } \\
\text { siswa } & \\
\end{array}$ & 97 & 66 & 21 & 16 & 200 & 844 & 4.22 & SB \\
\hline 37 & $\begin{array}{l}\text { Kepala sekolah } \\
\text { menciptakan } \\
\text { keamanan dan } \\
\text { ketertiban khususnya } \\
\text { di lingkungan sekolah }\end{array}$ & 95 & 67 & 20 & 18 & 200 & 839 & 4.195 & SB \\
\hline 38 & $\begin{array}{l}\text { Kepala sekolah } \\
\text { menciptakan suasana } \\
\text { kebersama-an di } \\
\text { lingkungan sekolah }\end{array}$ & 104 & 59 & 19 & 18 & 200 & 849 & 4.245 & SB \\
\hline 39 & $\begin{array}{lr}\text { Kepala } & \text { sekolah } \\
\text { memenuhi } & \text { segala } \\
\text { kebutuhan } & \text { yang } \\
\text { dibutuhkan } & \text { untuk } \\
\text { kegiatan sekolah }\end{array}$ & 89 & 73 & 22 & 16 & 200 & 835 & 4.175 & SB \\
\hline 40 & $\begin{array}{l}\text { Kepala sekolah } \\
\text { memonitor } \\
\text { perkembangan } \\
\text { kualitas guru dan } \\
\text { para siswa }\end{array}$ & 99 & 64 & 21 & 16 & 200 & 846 & 4.23 & SB \\
\hline \multicolumn{8}{|c|}{ Rata Rata } & 4.213 & SB \\
\hline
\end{tabular}

Pada tabel tersebut dapat terlihat bahwa kuisioner tersebut dibagi menjadi empat indikator yaitu: perencanaan pada poin satu hingga lima, pengorganasian pada poin enam hingga dua belas, pengarahan pada poin tiga belas hingga dua puluh tujuh, pengawasan pada point dua puluh delapan hingga empat puluh.

Dari indikator pertama yaitu perencanaan terlihat rata rata dari respon para responden (guru) pada SMK Negeri di wilayah Kota Tangerang Selatan (SMKN 1 , SMKN 2, SMKN 3, SMKN 4, SMKN5, SMKN 6, dan SMKN 7) adalah sangat baik dengan perolehan hasil rata rata yaitu 4,19. Dari indikator kedua yaitu pengorganasian terlihat rata rata dari respon para responden (guru) pada SMK Negeri di wilayah Kota Tangerang Selatan (SMKN 1, SMKN 2, SMKN 3, SMKN 4, SMKN 5, SMKN 6, dan SMKN 7) adalah sangat baik dengan perolehan hasil rata rata yaitu 4,23. 
Dari indikator ketiga yaitu pengarahan terlihat rata rata dari respon para responden (guru) pada SMK Negeri di wilayah Kota Tangerang Selatan (SMKN 1 , SMKN 2, SMKN 3, SMKN 4, SMKN5, SMKN 6, dan SMKN 7) adalah sangat baik dengan perolehan hasil rata rata yaitu 4,22 .

Dari indikator keempat yaitu pengawasan terlihat rata rata dari respon para responden (guru) pada SMK Negeri di wilayah Kota Tangerang Selatan (SMKN 1 , SMKN 2, SMKN 3, SMKN 4, SMKN5, SMKN 6, dan SMKN 7) adalah sangat baik dengan perolehan hasil rata rata yaitu 4,21 .

\section{KESIMPULAN}

Berdasarkan data yang telah di kumpulkan dan dilakukan oleh peneliti mengenai analisis manajerial kepala sekolah sehingga mewujudkan sekolah yang bermutu, maka dapat di tarik kesimpulan untuk menjawab rumusan masalah terkait :

1. Kompetensi manajerial kepala sekolah menengah kejuruan negeri di Kota Tangerang Selatan dalam peningkatan mutu, yaitu :

a. Peningkatan mutu yang ada saat ini yakni dengan merencanakan pembiayaan gratis untuk anak yang kurang mampu dan berprestasi sehingga tersusun dalam RKAS sesuai dengan kriteria sekolah. Yaitu kepala sekolahmerencanakan visi di jabarkan dalam bentuk program kerja jangka pendek, jangka menengah dan program jangka panjang yang terencana.

b. Pengembangan sekolah agar tercipta sekolah yang bermutu yaitu dengan merencanakan misi sekolah dan adanya kepemimpinan yang kuat, proses belajar mengajar yang tinggi, lingkungan sekolah yang aman dan tertib, pengelolaan pendidikan yang efektif, memiliki team work yang kompak cerdas dan dinamis, partisipasi yang tinggi dari masyarakat, memiliki komunikasi yang baik, lulusan yang terbaik dapat masuk ke perguruan tinggi negeri atau swasta dengan cara beasiswa serta ada juga yang langsung bekerja di dunia industri.

c. Kompetensimanajerial kepala sekolah mampu meningkatkan kualitas sekolah dengan cara membuat perencanaan yang matang serta dapat diimplementasikan secara nyata, dan terstruktur. Serta melakukan evaluasi secara terjadwal.

d. Secara keseluruhan kompetensi kepala SMK Negeri di Kota Tangerang Selatan secara garis besar sudah berkualitas, hal itu terlihat dengan meningkat prestasi peserta didik dan jumlah peminat untuk menjadi peserta didik.

2. Strategi kompetensi kepala sekolah menengah kejuruan dalam peningkatan mutu :

a. Menjalin kerjasama/MOU dengan lembaga pengembangan pendidikan dan Manajerial

b. Promosi dan marketing terhadap Branding yang dimiliki SMK Negeri

c. Menambah referensi-referensi baru, penggalian pengetahuan/teori yang yang terkini/ Konsultan pendidikan

d. Menambah perluasan pengelolaan SDM

e. Membuat maupun melengkapi sarana dan prasarana guna mendukung pengembangan manajerial 


\section{REFERENSI}

Ali, Muhammad. 2010. Metodologi dan Aplikasi Riset Pendidikan. Bandung: Penerbit Pustaka Cendikia Utama.

Bush, T \& M. Coleman. 2002. Leadership and Strategic Management in Education. London: A Sage Publications Company.

Depdiknas. 2007. Permendiknas Nomor 13 Tahun 2007 tentang Standar Kepala Sekolah,.Biro Hukum:Kemendiknas.

Drucker, P. F. 2007. Management Challenges for The Twenty-First Century. England: Routledge.

Handoko, T. Hani. 2007. Manajemen Personalia dan Sumberdaya Manusia, Edisi Cetakan Keempat belas. BPFE. Yogyakarta.

Kemdiknas. 2013. Kompetensi Manajerial Kepala Sekolah. Berita. http://www. kemdiknas.go.id/kemdikbud/berita/14 03.

Kahn, W.A. 1990. Psychological Conditions of Personal Engagement and Disengagement of Work. Academy of Management Journal, 33(4), 692-724. http://dx.doi.org/10.2307/256287

Marwanto, Benyamin Situmorang, dan Paningkat Siburian. 2017 The Analysis of Headmaster of Sma's Supervision Competence Guidance By Supervisor in Aceh Tengah District ( Aceh, 2017 )

Exposure : IOSR Journal of Research \& Method in Education (IOSR-JRME) e-ISSN: 2320-7388,p-ISSN: 2320-737X Volume 7, Issue 6 Ver. II (Nov. - Dec. 2017), PP 24-26 www.iosrjournals.org

Mulyasa, E. 2009. Menjadi Kepala Sekolah Profesional, Cetakan 11. Bandung: Penerbit RemajaRosdakarya.

Nellitawati, Nellitawati. 2017. The Contribution of headmaster's personality competencce to the teacher's social competence of vocational high school (Padang, 2017)Exposure : The International Journal of Counseling and Education, Vol.2, No.1, March 2017, pp. 25-34

Rahman at. all,. 2006. Peran Strategis Kepala Sekolah dalam Meningkatkan Mutu Pendidikan, Jatinangor: Penerbit Alqaprint.

Rangkuti, Freddy. 2018. Analisis SWOT : Teknik Membedah Kasus Bisnis Cara Perhitungan Bobot, Rating, dan OCAI. Jakarta: PT. Gramedia Pustaka

Rosalina, Risa. 2013. Persepsi Guru tentang Kompetensi Manajerial Kepala sekolah di Sekolah Dasar Negeri Kecamatan Padang Timur Kota Padang. Jurnal Administrasi Pendidikan.

Rotundo, M., \& Sackett, P.R. 2002. The Relative Importance of Task, Citizenship, and Counterproductive Performance to Global Ratings of Job Performance: A PolicyCapturing Approach. Journal of Applied Psychology, 87(1), 66-80. http://dx.doi.org/10.1037/0021-9010.87.1.66

Samsudin, Sadili. 2006. Manajemen Sumber Daya Manusia. Bandung: Penerbit CV Pustaka Setia.

Sapre, P. 2002. Educational Management and Administration. India: Sterling Publisher.

Sugiyono, 2010. Memahami Penelitian Kualitatif, Bandung: CV Alfabeta.

Terry, G.R.1986. The Principles of Management. Homewood Illinois: Richard Irwin.

Undang-Undang Republik Indonesia Nomor 20 Tahun 2003, Tentang Sistem Pendidikan Nasional (sisdiknas). Bandung: Penerbit Citra Umbara. 